\title{
Feeding response and carbon assimilation by the blue mussel Mytilus trossulus exposed to environmentally relevant seston matrices
}

\author{
Zainal Arifin ${ }^{1,2}$, Leah I. Bendell-Young ${ }^{1, *}$ \\ ${ }^{1}$ Department of Biological Sciences, SFU, Burnaby, British Columbia, Canada V5A 1S6 \\ ${ }^{2} \mathrm{R} \&$ D Center for Oceanology, LIPI, Poka, Ambon 97233, Indonesia
}

\begin{abstract}
The feeding response of the blue mussel Mytilus trossulus exposed to environmentally relevant seston matrices were studied in the laboratory under flow-through conditions. Twelve seston matrices varying in quality and quantity were prepared by mixing 3 microalga Thalassiosira pseudonana $\left(5,20\right.$ and $150 \times 10^{6}$ cells $\left.\mathrm{l}^{-1}\right)$ and 4 silt concentrations $\left(0,5,20\right.$ and $\left.50 \mathrm{mg} \mathrm{l}^{-1}\right)$ to represent an increasing seston organic quality of 10 to $71 \%$ and an increasing seston quantity of 1.4 to $56.6 \mathrm{mg} \mathrm{l}^{-1}$. Clearance rates (CRs), pseudofaeces (PF) production, sorting efficiency (SEF), ingestion rates (IRs) of particulate organic matter (POM) and particulate inorganic matter (PIM) and apparent and true carbon assimilation efficiencies (C-AE\%) were determined for the various exposure regimes. Under conditions of 0 and $5 \mathrm{mgl} \mathrm{l}^{1}$ silt, CRs decreased by 3 -fold $\left[14.4\right.$ to $4.9 \mathrm{l} \mathrm{h}^{-1} \mathrm{~g}^{-1} \mathrm{dry}$ wt (gdw-1)] and 6-fold (18.0 to $3.3 \mathrm{I} \mathrm{h}^{-1} \mathrm{gdw}^{-1}$ ) respectively, with increasing seston quality. Under conditions of high silt loads (20 and $\left.50 \mathrm{mg}^{-1}\right)$ CRs were independent of increasing seston quality with maximum CRs $\left(21.8 \pm 2.21 \mathrm{~h}^{-1}\right.$ $\mathrm{gdw}^{-1}$ ) observed at the $20 \times 10^{6}$ cells $\mathrm{l}^{-1}$ and $20 \mathrm{mg} \mathrm{l}^{-1}$ silt exposures. PF production was dependent on seston quantity $\left(r^{2}=0.63 ; p<0.05\right)$ with mussels preferentially rejecting the inorganic versus the organic component of the seston. This SEF was optimized at a seston quality of $40 \%$ organic matter. As a consequence of this selective feeding strategy, determined POM IRs under high algae/high silt (high quantity/quality) exposure regimes were comparable to those of the high quality (just algae) exposures (POM IRs of 48.0 as compared to 38.1 and $91.3 \mathrm{mg} \mathrm{h}^{-1} \mathrm{gdw}^{-1}$ for high quality and high quantity/quality respectively). In contrast, mussels exposed to low quality/quantity seston ingested both seston components (SEF $<24 \%$, i.e. the mussel was non-selective, possibly ingesting both seston components to meet nutrient requirements. Apparent $C-A E \%$ expressed as $C_{\text {seston }}-C_{\text {faeces }} / C_{\text {seston }}$ correlated with seston quality $\left(\%\right.$ POM) $\left(\mathrm{r}^{2}=0.64, \mathrm{p}<0.05\right)$. However, carbon assimilation expressed as a true $\mathrm{C}-\mathrm{AE} \%$, $C_{\text {diet }}-C_{\text {faces }} / C_{\text {diel }}$, was independent of seston quality as was carbon assimilation rate (the product of the amount of ingested organic matter and carbon assimilation efficiency). Hence, through a dynamic interplay between CRs and carbon assimilation efficiency, the blue mussel was able to maintain a constant rate of carbon assimilation, regardless of the quality and quantity of seston to which it was exposed. This compensatory feeding strategy displayed by the blue mussel has important implications for predictive models which relate contaminant uptake to a diet/energy pathway. Contaminant uptake may be either underestimated or overestimated if the ability of the blue mussel to optimize nutrient gain under a variety of seston compositions has not been taken into account.
\end{abstract}

KEY WORDS: Mytilus trossulus - Feeding behaviour - Sorting process Pseudofaeces Ingestion rate Assimilation of carbon

\section{INTRODUCTION}

Within estuarine environments, one of the main suspension feeders, of both economic and ecological im-

-Addressee for correspondence.E-mail: bendell@sfu.ca portance, is a species complex of blue mussel (Mytilus edulis L., M. galloprovincialis Lamarck, and $M$. trossulus Gould). As a result of its global distribution and its ability to concentrate metals from its environment, the blue mussel has been used world-wide for pollution monitoring programs. Given its importance, much 
study has focused on how biotic factors such as size sex and growth rates influence tissue metal burdens (Cossa et al. 1979, Poulsen et al. 1982, Lobel et al 1991). More recent studies have been directed at determining the underlying physiological mechanisms that influence metal accumulation by filter-feeding organisms. For example, Wang et al. (1995) related the amount of metal accumulation by bivalves to gut passage time and digestive partitioning. Decho \& Luoma (1996) noted that bivalves were capable of modifying the digestive processing of food to reduce exposure to biologically available chromium concentrations. Wang \& Fisher (1996) suggested that for some metals, assimilation is related to the degree of carbon assimilation by the mussel, i.e. that metal assimilation and hence accumulation by the mussel follows a diet/energy pathway. We know of no studies, however, which have assessed the possible role of feeding behaviour in determining the amount of metal to which the mussel is exposed to via its diet and hence amounts of metal that are potentially available for uptake and accumulation by the filter-feeding mussel.

Currently, there is much controversy in the literature in regards to whether filter feeders have a selective feeding strategy (e.g. Bayne et al. 1993) or whether filter-feeding is a highly automated process characterized by the full exploitation of the filter-pump to process the ambient water under optimal conditions (e.g. Jørgensen 1990). Bayne et al. (1993) found that blue mussels fed at high concentrations of seston of relatively low organic content $40 \%$ particulate organic matter) increased their filtration rate, rejected a higher proportion of filtered material as pseudofaeces, and increased the efficiency with which filtered matter of higher organic content was selected for ingestion. These changes in response to a changing food environment by the mussel resulted in higher rates of carbon absorption than would have been predicted based on the assumptions of a non-compensating feeding behaviour. In contrast, based on their studies of growth, filtration and respiration in the blue mussel, Clausen \& Riisgård (1996) concluded that there was no evidence for physiological regulation of the filtration rate to meet nutritional needs and that as claimed by Jørgensen (1990), food uptake in nature was characterized by the full exploitation of the capacity of the bivalve filter-pump.

If mussels are highly selective as suggested by Bayne et al. (1993), then the 'diet' of the mussel (i.e. that component of the seston that the animal is actually ingesting) and the subsequent absorption of carbon from the diet have the potential of being completely different from that which would be expected based on in situ measurements of seston within the environment and what the mussels are supposedly feeding on. This has important implications for predictive models of metal accumulation by seston-ingesting organisms that link metal assimilation to the organic content of the 'diet' (e.g. Wang \& Fisher 1996). If mussels are capable of a compensatory feeding strategy, as proposed by Bayne et al. (1993), which leads to a relative enhancement of net energy and nutrient acquisition over that which would be predicted based on the organic/inorganic composition of the seston matrix, then predictive models of metal (and organic) contaminant uptake, based on a diet/energy pathway, may underestimate amounts of contaminants to which the mussels are actually exposed.

Hence, the objective of our study was to determine the feeding response of the blue mussel to environmentally relevant seston matrices which varied in both quality and quantity. Specifically we were interested, first, in determining the degree to which the mussel could alter its food environment (i.e. was the 'diet' that the mussel ingested the same as the seston matrix to which it had been exposed) given a wide range of environmentally relevant seston matrices, and second, in determining the corresponding carbon assimilation efficiencies for the 'diet' as selected for by the mussel.

To meet these objectives, changes in the following physiological attributes in the blue mussel Mytilus trossulus exposed to the various seston matrices were assessed: (1) clearance rate, (2) pseudofaeces production, (3) sorting efficiency, (4) particulate organic and inorganic matter ingestion rates, (5) apparent and true carbon assimilation efficiencies and (6) carbon assimilation rates. Seston quality and quantity were chosen to represent seasonal and tidal patterns in seston quality and quantity found under natural conditions (i.e. within the estuarine environment) (Berg \& Newell 1986. Smaal et al. 1986, Fegley et al. 1992, Galois et al. 1996, Stecko 1997). Ultimately this information will be used in predictive models of metal accumulation in bivalves based on a selective feeding strategy which optimizes for the assimilation of carbon under a range of environmental conditions.

\section{MATERIALS AND METHODS}

Experimental mussels. Mussels Mytilus trossulus Gould, 1850 were collected from an intertidal area on the west coast of British Columbia (within Howe Sound), Canada. Collected mussels were placed in a cooler, and transported to the laboratory at the Department of Biological Sciences, Simon Fraser University Mussels $[44.9 \pm 2.07 \mathrm{~mm}$ in shell length (SL)] were acclimatized to experimental conditions (temperature $13 \pm 1^{\circ} \mathrm{C}$; salinity: $28 \mathrm{ppt}$ ) for $2 \mathrm{wk}$ prior to use in each experiment. Throughout the acclimation period, the 
mussels were fed the diatom alga Thalassiosira pseudonana daily, and the seawater was changed on a regular basis. Prior to the feeding experiments, mussels were separated from their basal attachments to one another, brushed clean and kept for approximately 15 min under dry air. This procedure ensured that only live mussels were used in the experiments, as those mussels that were not viable did not respond to being submerged in seawater following the 15 min exposure to air.

Experimental apparatus. Feeding behaviour experiments were conducted under flow-through conditions in $500 \mathrm{ml}$ plexiglass tanks. An 18 l source of filtered seawater was provided by sequentially filtering supplied seawater through 5.0 and $1.0 \mu \mathrm{m}$ cartridge filters (Labcor Inc.). The seston matrices were prepared immediately before use by adding known volumes of algae culture and silt suspension into a polyethylene tank and subsequent dilution of the 2 seston components to a volume of $18 \mathrm{l}$ with the prepared filtered seawater.

Seston (suspended particulate matter). A review of the literature indicated a wide range in in situ nearshore and estuarine seston quantity $\left(0.3\right.$ to $200 \mathrm{mg} \mathrm{l}^{-1}$ ) and quality ( 3 to $48 \%$ organic matter) (Table 1 ). To represent this range, seston matrices were manipulated such that quality ranged from 10 to $50 \%$ organic matter and quantity from 1.4 to $56.6 \mathrm{mg} \mathrm{l}^{-1}$. The highest seston quality was $71 \%$ organic matter for the algae alone treatment. Experimental seston was made by mixing diatom cells of Thalassiosira pseudonana with kaolinitic mineral (ASP 400-P) to represent the organic and inorganic component of the seston, respectively. Twelve seston matrices varying in quality and quantity were prepared by mixing 3 diatom concentrations $\left(5,20\right.$ and $150 \times 10^{6}$ cells $\left.1^{-1}\right)$ and 4 silt concentrations $\left(0,5,20\right.$, and $\left.50 \mathrm{mg} \mathrm{l}^{-1}\right)$. Algae were obtained from the North East Pacific Culture Collection (NEPCC), University of British Columbia, Canada. Non-axenic cultures of the algae were grown in aerated $4 \mathrm{l}$ flasks in Harrison medium (Harrison et al. 1980 ), at $16^{\circ} \mathrm{C}$ and under $14 \mathrm{~h}$ dark: $10 \mathrm{~h}$ light illumination $\left(188 \mu \mathrm{E} \mathrm{m}^{-2} \mathrm{~s}^{-1}\right)$. Twelve litres of the algae were prepared in each experiment. The kaolinitic mineral (ASP 400-P) was obtained from the Engelhard Corp. Particle size distribution was determined on 10 replicates with an electronic particle counter (model TAII), fitted with a $100 \mu \mathrm{m}$ aperture tube. Particle size ranged from 2.0 to $25.5 \mu \mathrm{m}$. Prior to each experiment, a stock slurry was prepared by suspending a predetermined weight of silt in $1 \mathrm{l}$ of filtered seawater $(0.45 \mu \mathrm{m})$. The slurry was dispersed with an electric stirrer and an ultrasonic bath before mixing with algae in the experimental tank. The concentrated seston was delivered into a $1.5 \mathrm{l}$ mixing chamber by peristaltic pump. From the mixing chamber, the suspension was delivered at a flow rate of $110 \mathrm{ml} \mathrm{min} \mathrm{m}^{-1}$ to four $500 \mathrm{ml}$ plexiglass experimental tanks of which three contained mussels. The fourth remained empty and was used as a control.

Seston C:N ratios. Seston organic carbon and nitrogen content for calculation of $\mathrm{C}: \mathrm{N}$ seston ratios was determined in triplicate using a Carlo Erba elemental analyser (Model 1106) with acetanilide $\left(\mathrm{C}_{6} \mathrm{H}_{5} \mathrm{NHCOCH}_{3}\right)$ as a standard.

Physiological measurements. An overview of the various experimentally determined behavioural and physiological parameters is presented in Fig. 1. A summary of abbreviations used in quantifying the behavioural and physiological parameters is presented in Table 2. From October 1995 to February 1996, 12 seston matrices were randomly assigned and prepared. Seston composition and physiological parameters were determined in triplicate as follows:

Table 1. Seston concentration ( $\mathrm{mg} \mathrm{l}^{-1}$ ) and seston quality (\% POM) of coastal ecosystems. Monthly measurement of SPM for 12 to 18 mo

\begin{tabular}{|c|c|c|c|}
\hline Location & Seston $\left(\mathrm{mg} \mathrm{l}^{-1}\right)$ & $1 \%$ POM & Reference \\
\hline \multicolumn{4}{|l|}{ Near-shore } \\
\hline Logy Bay, NF (Canada) & $0.3-3.0$ & $7.5-48.0$ & Navarro \& Thompson (1995) \\
\hline Tromse (Norway) & $5.0-12.0$ & $20.0-33.0$ & Vahl (1980) \\
\hline Great Sound, NJ (USA) a & $35.0-80.0$ & $10.0-20.0$ & Fegley et al. (1992) \\
\hline False Bay (South Africa) & $2.0-152.0$ & $10.0-30.0$ & Griffiths (1980) \\
\hline Yaldad Bay (South of Chile) & $3.7-48.0$ & $32.0-37.5$ & Navarro et al. (1993) \\
\hline \multicolumn{4}{|l|}{ Estuary } \\
\hline Lynher Estuary (England) & $4.0-35.0$ & $5.0-37.0$ & Widdows et al. (1979) \\
\hline Fort Boyard (France) & $3.0-24.0$ & $10.0-35.0$ & Galois et al. (1996) \\
\hline Wadden Sea (The Netherlands) & $20.0-40.0$ & $10.0-12.5$ & Smaal et al. $\{1986\}$ \\
\hline Fraser River Estuary (Canada) & $4.5-32.0$ & $3.0-23.0$ & Stecko $(1997)$ \\
\hline Upper Chesapeake Bay (USA) & $3.5-30.0$ & $27.0-43.0$ & Berg \& Newell (1986) \\
\hline Chesapeake Bay (USA) ${ }^{b}$ & $20.0-200.0$ & - & Schubel (1971) \\
\hline
\end{tabular}




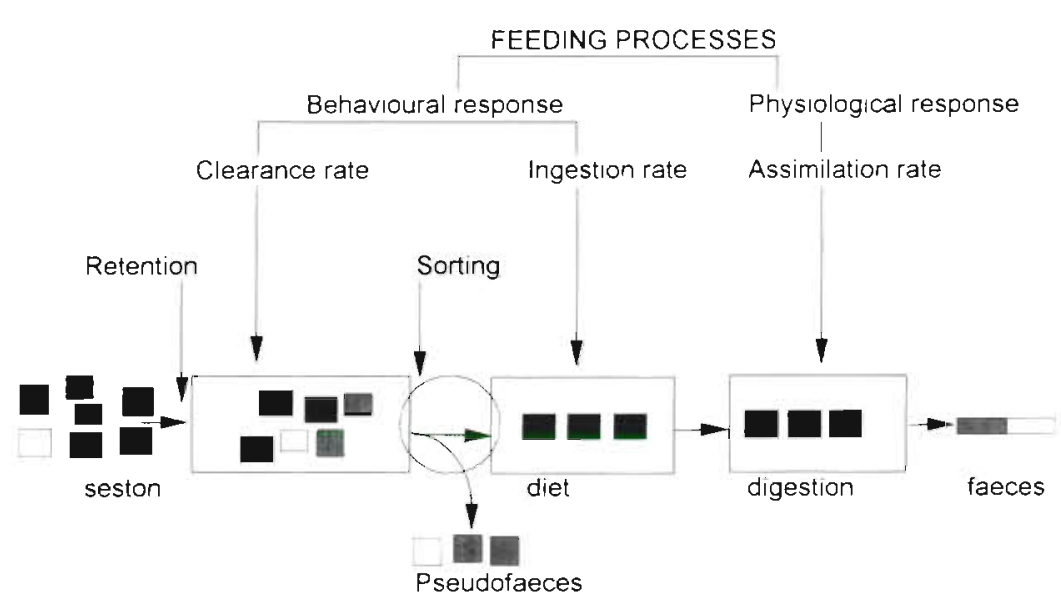

Fig. 1 Overview of the various behavioural and physiological parameters measured of seawater to the 2 seston components. After passing through the 5.0 and $1.0 \mu \mathrm{m}$ filters the particle concentration of the filtered seawater still averaged $2.56 \mathrm{mg} \mathrm{l}^{-1}$. This particulate material. consisted of $1.03 \mathrm{mg} \mathrm{PIM} \mathrm{l}^{-1}$ and $1.53 \mathrm{mg}$ POM 1 $^{-1}$. Vahl (1972) noted that ctenidia of mussels will retain a particle size as small as $2.00 \mu \mathrm{m}$. In general, smaller particles (less than $<1.00 \mu \mathrm{m}$ in filtered seawater) are not retained. Thus, although the filtered seawater had an average of $2.56 \mathrm{mg} \mathrm{l}^{-1}$ seston, it would not be biologically available to the mussels. However, the seawater inorganic and organic components would have influenced the determined inorganic and organic concentrations in the ses-

Seston matrices: One litre of each seston matrix was filtered through pre-weighed $0.45 \mu \mathrm{m}$ GF/F filters (Whatman) and rinsed with seawater-isotonic ammonium formate $(0.5 \mathrm{M})$. To determine seston quantity, filtered samples were dried to a constant weight $\left(60^{\circ} \mathrm{C}\right.$ for $96 \mathrm{~h}$ ) and the final weight recorded. Seston quantity was expressed as the concentration of suspended particulate matter (SPM: $\mathrm{mg} \mathrm{l}^{-1}$ ) and was based on total dry weight per litre of suspended material recovered from the experimental chambers. To determine seston quality, the dried samples were further ashed in a muffle furnace $\left(450^{\circ} \mathrm{C}\right.$ for $\left.6 \mathrm{~h}\right)$ before final weighing. The seston inorganic component (PIM: $\mathrm{mg} \mathrm{l}^{-1}$ ) was determined as the remaining weight of the ashed sample. The particulate organic seston (POM: $\mathrm{mg} \mathrm{l}^{-1}$ ) was calculated by subtracting PIM from SPM.

An important correction that needed to be made on measured concentrations of seston organic and inorganic concentrations was the inadvertent contribution ton matrices. Hence, seston composition was corrected for the influence of seawater as follows:

$$
\begin{aligned}
& \mathrm{SPM}_{\text {uncorrected (uc) }}=\mathrm{PIM}+\mathrm{POM} \\
& \mathrm{SPM}_{\text {corrected }(c)}=\left(\mathrm{PIM}-\text { Seawater }_{\mathrm{PIM}}\right) \\
& +\left(\mathrm{POM}-\text { Seawater }_{\mathrm{POM}}\right) \\
& =\mathrm{PIM}_{\mathrm{c}}+\mathrm{POM}_{\mathrm{c}}
\end{aligned}
$$

Clearance rate measurements: Clearance rate (CR) is a measure of the volume of water from which particles have been removed by the mussels per unit time [i.e. $\mathrm{l} \mathrm{h}^{-1} \mathrm{~g}^{-1}$ dry $\mathrm{wt}\left(\mathrm{gdw}^{-1}\right)$ ]. The clearance rate was determined as described by Vahl (1973). The flow rate through the experimental tanks was maintained at $110 \mathrm{ml} \mathrm{min}{ }^{-1}$. An individual mussel was allowed to acclimate to experimental conditions for $30 \mathrm{~min}$ before the clearance rate was measured. During the course of the experiment ( $4 \mathrm{~h}$ exposure to a seston matrix),

\begin{tabular}{|c|c|c|}
\hline Parameter & Definition & Units \\
\hline $\mathrm{SPM}_{\text {uncorrected (uc) }}$ & Suspended particulate matter uncorrected for seawater contribution & $\mathrm{mg} \mathrm{l}^{-1}$ \\
\hline SPM corrected icl & $\mathrm{SPM}_{u c}$ corrected for seawater contribution & $\mathrm{mg} \mathrm{l}^{-1}$ \\
\hline POMc $_{C}$ & Particulate organic matter corrected for organic component of seawater & $\mathrm{mg} \mathrm{l}^{-1}$ \\
\hline $\mathrm{PIM}_{c}$ & Particulate inorganic matter corrected for inorganic component of seawater & $\mathrm{mg} \mathrm{l}^{-1}$ \\
\hline $\mathrm{SQ}$ & Seston quality & $\%$ \\
\hline CR & Clearance rate & $1 \mathrm{~h}^{-1} \mathrm{gdw}^{-1}$ \\
\hline $\mathrm{PF}_{\mathrm{ur}}$ & Pseudofaeces production uncorrected for seawater contribution & $\mathrm{mg} \mathrm{h}^{-1} \mathrm{gdw}^{-1}$ \\
\hline $\mathrm{PF}_{\varsigma}$ & $\mathrm{PF}_{\mathrm{uc}}$ corrected for seawater contribution & $m g h^{-1} g d w^{-1}$ \\
\hline SEF & Sorting efficiency & $\%$ \\
\hline $\mathrm{IR}_{\mathrm{u}}$ & Ingestion rate based on $\mathrm{CR} \times \mathrm{SPM}_{\mathrm{C}}$ & $\mathrm{mg} \mathrm{h}^{-1} \mathrm{gdw}^{-1}$ \\
\hline $\mathrm{IR}_{c}$ & Ingestion rate corrected for $\mathrm{PF}_{\mathrm{c}}$ & $\mathrm{mg} \mathrm{h}^{-1} \mathrm{gdw}^{-1}$ \\
\hline App C-AE\% & Apparent carbon assimilation efficiency & $\%$ \\
\hline True $C-A E \%$ & True carbon assimilation eff $\mathrm{ciency}$ & $\%$ \\
\hline $\mathrm{AR}$ & Absorption rate, the product of true C-AE\% and IR-POMr & $\mathrm{mgCh} \mathrm{h}^{-1} \mathrm{gdw}^{-1}$ \\
\hline
\end{tabular}
suspended particles were collected from the control and treatment tanks every 15 min. The particles were

Table 2. Summary of the various abbreviations, and their meanings and units, used in Eqs. (1) to (12) 
counted with a Coulter Counter TA II with a $100 \mu \mathrm{m}$ aperture tube. Clearance rates were generally independent of time, that is, the rates did not increase or decrease over the $4 \mathrm{~h}$ exposure period (Fig. 2). Clearance rates were calculated as follows:

$$
\mathrm{CR}=\mathrm{FR} \times\left(1-C_{\mathrm{l}} / C_{\mathrm{c}}\right)
$$

where FR is flow rate $\left(\mathrm{ml} \mathrm{min}^{-1}\right)$, and $C_{\mathrm{t}}$ and $C_{\mathrm{c}}$ are the particle concentrations (no. of particles $\mathrm{l}^{-1}$ ) in treatment and control tanks, respectively.

Determinations of pseudofaeces production: Pseudofaeces production ( $\mathrm{PF}, \mathrm{mg} \mathrm{h} \mathrm{h}^{-1} \mathrm{gdw}^{-1}$ ) is any particle that is cleared from suspension but rejected by the gills and palps (Widdows et al. 1979). Pseudofaeces were readily distinguished from faeces and consisted of a light fluffy texture as compared to faeces which were 'packaged' and resembled a long flat string. All pseudofaeces generated by the mussel under the various exposure regimes were collected from the experimental tanks by capillary pipette. The rate of pseudofaeces production for a 4 h exposure period, corrected for the contribution from seawater, was determined as:

$$
\begin{aligned}
\mathrm{PF}_{\mathrm{UC}} & =\mathrm{PF}_{\mathrm{PIM}}+\mathrm{PF} \mathrm{FPM}_{\mathrm{PO}} \\
\mathrm{PF}_{\mathrm{c}} & =\left(\mathrm{PF}_{\mathrm{PIM}}-\text { Seawater }_{\mathrm{PIM}}\right)+\left(\mathrm{PF}_{\mathrm{POM}}-\text { Seawater }_{\mathrm{POM}}\right) \\
& =\mathrm{PF}_{\mathrm{PIM}, \mathrm{c}}+\mathrm{PF}_{\mathrm{POM}, \mathrm{c}}
\end{aligned}
$$

Faeces production and carbon content: Total faeces generated throughout the $4 \mathrm{~h}$ exposure period were collected from the experimental tanks by capillary pipette. Recovered faeces were dried (at $60^{\circ} \mathrm{C}$ for $96 \mathrm{~h}$ ), weighed and total mass of faeces generated per gram dry weight of mussel for the $4 \mathrm{~h}$ exposure period obtained. Carbon content of the faeces was determined using a Carlo Erba elemental analyser (Model 1106) with acetanilide $\left(\mathrm{C}_{6} \mathrm{H}_{5} \mathrm{NHCOCH}_{3}\right)$ as a standard.

Estimation of sorting efficiency: Sorting efficiency (SEF) is defined as the retention, discrimination and ingestion of one particle type in preference to another (MacDonald \& Ward 1994). SEF was estimated based on the ratio of seston quality and pseudofaeces quality, where quality is the percentage of organic matter in the seston and is calculated as:

$$
\mathrm{SEF}=[1-(\mathrm{PQ} / \mathrm{SQ})] \times 100 \%
$$

where PQ is the quality of the pseudofaeces (\% organic matter) and SQ is the quality of the seston (\% organic matter). Values of SEF ranged from 0\% (no selection; organic content of pseudofaeces and seston are equal) to $100 \%$ (full selection; no organic component remains in the pseudofaeces).

Ingestion rate calculations: Ingestion rate (IR, mg $\mathrm{h}^{-1} \mathrm{gdw}^{-1}$ ) was calculated as a product of the clearance
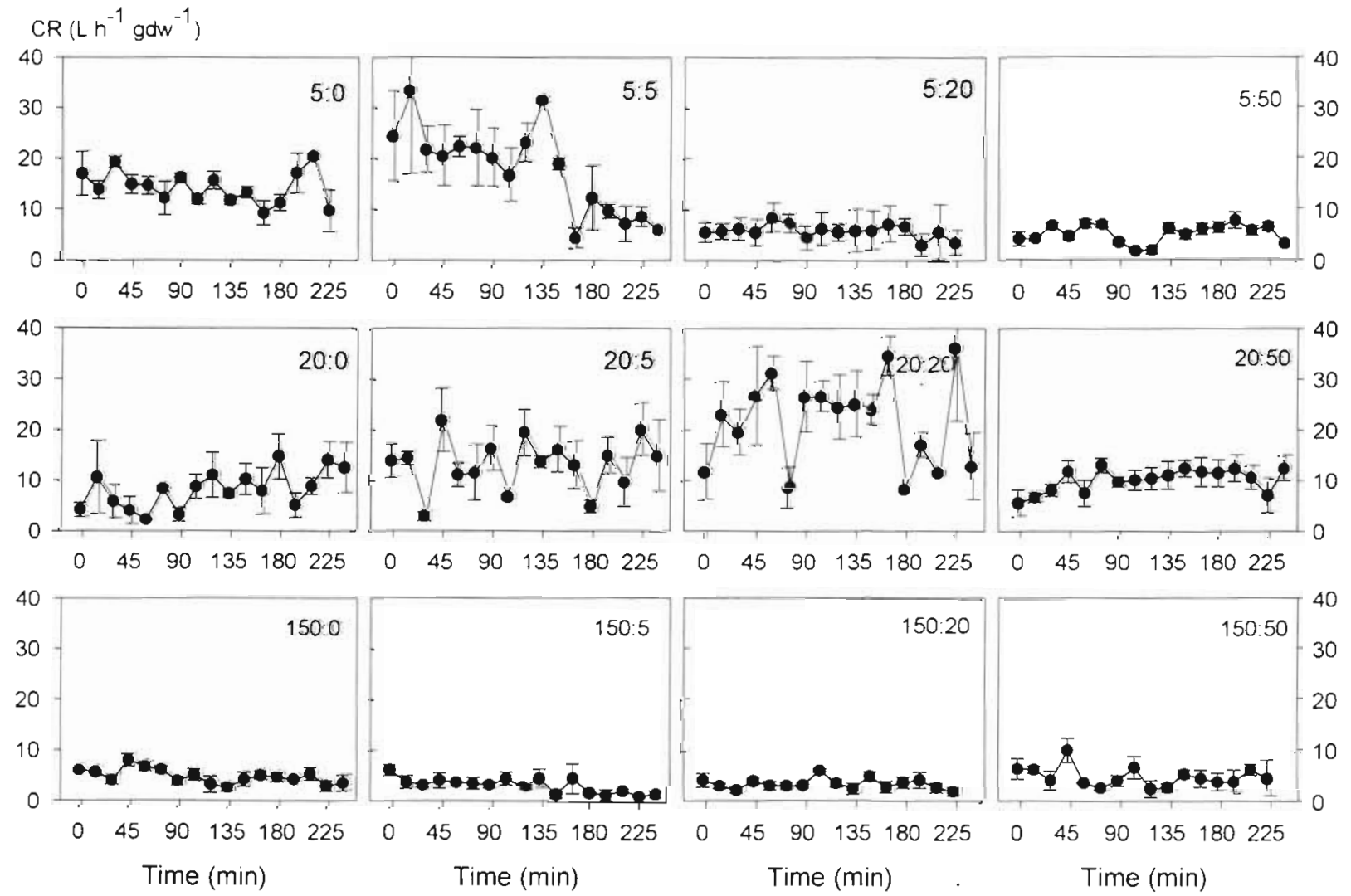

Fig. 2. Mytilus trossulus. Clearance rate ( $\pm \mathrm{SE}$ ) of mussels exposed to different seston matrices. Algae:silt ratios are given as algae $\left(\times 10^{6}\right.$ cells $\left.^{-1}\right)$ : silt $\left(\mathrm{mg} \mathrm{l}^{-1}\right)$ 
rate and the seston quantity minus pseudofaeces production

$$
\begin{aligned}
& \mathrm{IR}_{\mathrm{uc}}=\mathrm{SPM}_{\mathrm{c}} \times \mathrm{CR} \\
& \mathrm{IR}_{\mathrm{c}}=\mathrm{IR}_{\mathrm{uc}}-\mathrm{PF} \mathrm{F}_{\mathrm{c}}
\end{aligned}
$$

IRs were calculated for both organic and inorganic $\mathrm{SPM}_{\mathrm{c}}$ components (i.e. where $\mathrm{IR}_{\mathrm{c}}=\mathrm{IR}_{\mathrm{PIM}, \mathrm{c}}+\mathrm{IR}_{\mathrm{POM} \text {. }}$ and $P F_{C}=P_{P F M_{c}}+P_{P O M . c}$ ) and represents the actual 'diet' of the mussel, i.e. that component of the seston that is actually ingested after taking into account particle selection and subsequent rejection via $\mathrm{PF}_{c}$ production

Seston quality: Seston quality (SQ) was expressed as the ratio of the concentration of organic matter in seston per seston quantity $\left[\mathrm{SQ}=\left(\mathrm{POM}_{\mathrm{c}} / \mathrm{SPM}_{\mathrm{c}}\right) \times 100\right]$ (after Bayne et al. 1993) where both $\mathrm{POM}_{C}$ and $\mathrm{SPM}_{\mathrm{C}}$ are in units of $\mathrm{mg} \mathrm{l}^{-1}$.

Estimates of assimilation efficiency: Carbon assimilation efficieny ( $\mathrm{C}-\mathrm{AE} \%)$ is an estimate of the fraction of ingested seston that is incorporated by the mussel. Both apparent (app C-AE\%) and true (true C-AE\%) assimilation efficiency were calculated. App C-AE\% were based on the carbon content of faeces collected from treatment tanks and the carbon content of the seston matrix:

$$
\operatorname{app} C-A E \%=\left[\left(C_{\text {seston }}-C_{\text {iaces }}\right) / C_{\text {seston }}\right] \times 100
$$

True C-AE\% were based on estimates of the carbon content of the 'diet' which the mussel is actually ingesting (i.e. accounting for selection of organic versus inorganic particles) and the carbon content of faeces and were determined as:

$$
\text { true C-AE\% }=\left[\left(\mathrm{C}_{\text {diet }}-\mathrm{C}_{\text {faeces }}\right) / \mathrm{C}_{\text {diet }}\right] \times 100
$$

Carbon in the diet ( $\mathrm{mg} \mathrm{C}_{\text {diet }} \mathrm{gdw}^{-1}$ ) was estimated by multiplying amounts of $\mathrm{POM}_{\mathrm{c}}$ ingested by the mussel over a $4 \mathrm{~h}$ exposure period by the carbon content of algae [measured as $12 \% \pm 0.003 \mathrm{SE}$ by weight using a Carlo Erba elemental analyser (Model 1106) with acetanilide $\left(\mathrm{C}_{6} \mathrm{H}_{5} \mathrm{NHCOCH}_{3}\right)$ as a standard]. Carbon in faeces was determined as amount of faeces produced by a mussel for a $4 \mathrm{~h}$ exposure period multiplied by the carbon content of the produced faeces ( $\mathrm{mg} \mathrm{C}_{\text {faeces }} \mathrm{gdw}^{-1}$ ).

Statistical analysis. Statistical analysis for all data was performed using Minitab 10 software. Bartlett's test was applied for testing data homogeneity and, where necessary, transformations were applied to meet the assumptions of the ANOVA. 2-way ANOVAs were applied to determine: (1) differences among the various seston quality and quantity matrices and (2) differences in the behavioural and physiological responses of the mussels to the various matrices. Where ANOVA showed significant effects, Tukey's Honestly Significant Different (HSD) tests were applied to determine where the significant differences occurred. Regression analysis was applied to determine relationships between (1) CRs and seston concentrations, (2) CRs and $\mathrm{POM}_{c}\left(\mathrm{mg} \mathrm{l}^{-1}\right)$, (3) SEF and $S Q_{\text {, (4) } P F \text { and }}$ $S Q$, (5) app C-AE\% and $S Q$, (6) true $C-A E \%$ and $S Q$ and (7) carbon assimilation rate and SQ. Significance of all tests was accepted at $p \leq 0.05$.

\section{RESULTS}

\section{Quantity and quality of seston matrices}

The mean quantity of seston ( $\pm \mathrm{SE}$ ) ranged from $1.4 \pm$ 0.1 to $56.6 \pm 3.40 \mathrm{mg} \mathrm{l}^{-1}$ of which the mean values for organic content of seston were $1.0 \pm 0.04$ and $13.6 \pm$ $0.08 \mathrm{mg} \mathrm{l}^{-1}$, respectively (Table 3 ). The results of the ANOVA indicated significant differences in seston

\begin{tabular}{|c|c|c|c|c|c|}
\hline${ }_{\left(\times 10^{10} \text { cells } 1^{-1}\right)}^{\text {Sest }}$ & $\begin{array}{l}\text { Silt } \\
\left(\mathrm{mg} \mathrm{l^{-i }}\right)\end{array}$ & $\begin{array}{c}\mathrm{SPM}_{\mathrm{c}} \\
\left(\mathrm{mg} \mathrm{l^{-1 }}\right)\end{array}$ & $\begin{array}{l}\mathrm{POM}_{\mathrm{c}} \\
\left(\mathrm{mg} \mathrm{l}^{-1}\right)\end{array}$ & $\begin{array}{c}\mathrm{SQ} \\
\%\end{array}$ & C:N ratio \\
\hline $\begin{array}{l}5 \\
20 \\
150\end{array}$ & $\begin{array}{l}0 \\
0 \\
0\end{array}$ & $\begin{array}{r}1.4 \pm 0.10 \\
2.6 \pm 0.12 \\
15.7 \pm 3.45\end{array}$ & $\begin{array}{l}1.0 \pm 0.04 \\
1.8 \pm 0.13 \\
9.0 \pm 0.96\end{array}$ & $\begin{array}{l}71.4 \pm 0.01 \\
68.0 \pm 2.73^{\circ} \\
60.0 \pm 6.55^{b}\end{array}$ & $\begin{array}{l}6.3 \pm 0.11 \\
6.8 \pm 0.16 \\
5.7 \pm 0.06\end{array}$ \\
\hline $\begin{array}{l}5 \\
20 \\
150\end{array}$ & $\begin{array}{l}5 \\
5 \\
5\end{array}$ & $\begin{array}{r}5.4 \pm 0.12 \\
9.7 \pm 1.72 \\
14.4 \pm 4.11\end{array}$ & $\begin{array}{l}1.7 \pm 0.42 \\
1.9 \pm 0.55 \\
6.8 \pm 1.55\end{array}$ & $\begin{array}{l}30.6 \pm 2.72^{c} \\
18.2 \pm 3.02^{d} \\
48.5 \pm 2.57^{b}\end{array}$ & $\begin{array}{l}4.9 \pm 0.31 \\
5.6 \pm 0.23 \\
7.0 \pm 0.16\end{array}$ \\
\hline $\begin{array}{l}5 \\
20 \\
150\end{array}$ & $\begin{array}{l}20 \\
20 \\
20\end{array}$ & $\begin{array}{l}24.6 \pm 0.10 \\
25.1 \pm 1.21 \\
28.4 \pm 2.37\end{array}$ & $\begin{array}{r}2.9 \pm 0.33 \\
5.2 \pm 1.35 \\
12.2 \pm 0.74\end{array}$ & $\begin{array}{l}11.6 \pm 1.58^{\mathrm{d}} \\
20.6 \pm 5.06^{\mathrm{d}} \\
43.5 \pm 3.80^{\mathrm{bc}}\end{array}$ & $\begin{array}{l}7.2 \pm 0.44 \\
3.9 \pm 0.11 \\
6.5 \pm 0.09\end{array}$ \\
\hline $\begin{array}{l}5 \\
20 \\
150\end{array}$ & $\begin{array}{l}50 \\
50 \\
50\end{array}$ & $\begin{array}{l}30.4 \pm 1.65 \\
43.4 \pm 3.00 \\
56.6 \pm 3.40\end{array}$ & $\begin{array}{r}3.8 \pm 2.03 \\
4.5 \pm 0.16 \\
13.6 \pm 0.08\end{array}$ & $\begin{array}{l}14.9 \pm 5.51^{d} \\
10.3 \pm 0.25^{d} \\
24.1 \pm 1.62^{\mathrm{c}}\end{array}$ & $\begin{array}{l}5.2 \pm 0.11 \\
7.8 \pm 0.13 \\
5.9 \pm 0.10\end{array}$ \\
\hline
\end{tabular}

Table 3. Characteristics of seston matrices. $\mathrm{SPM}_{\digamma}=$ suspended particulate matter, $\mathrm{POM} \mathrm{M}_{\mathrm{c}}=$ particulate organic matter, $\mathrm{SQ}=$ seston quality (dry weight ratio of POM over SPM), C:N ratio = carbon:nitrogen ratio; values are means \pm SE. Significant $(\mathrm{p}<0.05$, Tukey's multiple range analysis) differences are denoted by different letters 
qualities $(p<0.05)$ among seston treatments which contained both algae and silt. Seston quality ranged from $10 \%\left(20 \times 10^{6}\right.$ cells $\mathrm{l}^{-1}$ and $50 \mathrm{mg} \mathrm{l}^{-1}$ silt $)$ to $71 \%$ (just algae alone). Seston C:N ratios remained relatively constant across all treatments (Table 3 ).

\section{Effect of seston matrices on clearance rates}

Results of the average (where each value is the mean of 3 mussels) CRs after the $4 \mathrm{~h}$ exposure to the various seston matrices are presented in Table 4 . Changes in algae concentration significantly affected mussel CRs (2-way ANOVA, $\mathrm{p}<0.05)$. Under no and medium silt exposures $\left(0\right.$ and $\left.5 \mathrm{mg} \mathrm{l}^{-1}\right)$, CRs decreased as seston quality and quantity increased, with as much as a $60 \%$ reduction between the low and high algae exposures under these 2 lowest silt regimes (Fig. 3). Surprisingly, maximum CRs were obtained under high silt $(20 \mathrm{mg}$

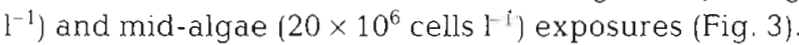

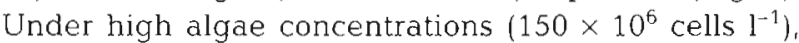
CRs were not significantly different from each other regardless of increasing silt load. When $C R s$ were regressed against increasing seston quantity $\left(\mathrm{SPM}_{C}\right.$, $\mathrm{mg} \mathrm{l}^{-1}$ ) (Fig. 4a) or quality (POM $\mathrm{C} \mathrm{mg} \mathrm{l}^{-1}$ ) (Fig. $4 \mathrm{~b}$ ), as a consequence of the variable response of CRs to the various food matrices, either no relationship (CRs vs SPM) or a weak relationship (CRs vs $\mathrm{POM}_{\mathrm{c} i} \mathrm{r}=0.54$, $p>0.05$ ) was observed.

\section{Effect of seston matrices on sorting efficiency}

Mean SEF (the ability to select organic particles over inorganic particles) of mussels ranged from -18 and $0 \%$, when exposed to low quality ( $\mathrm{SQ} \leq 18 \%$ ) and high

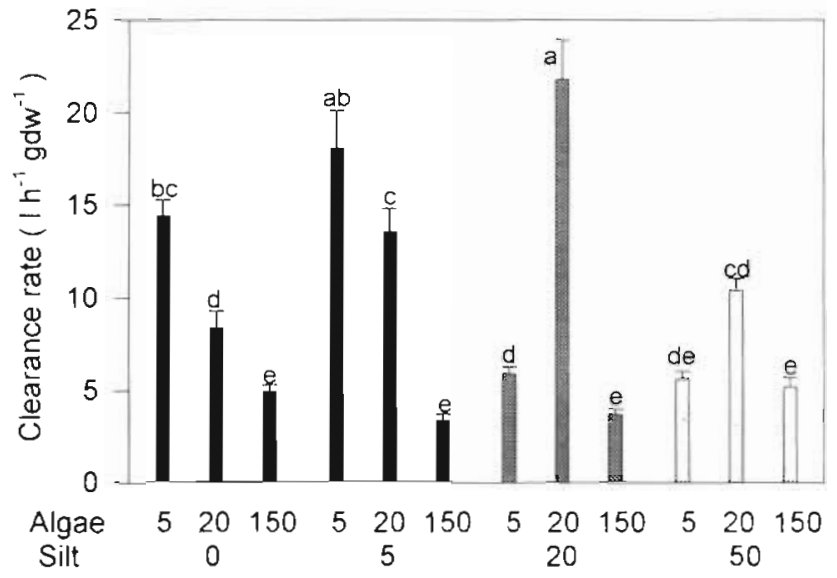

Fig. 3. Mytilus trossulus. Average clearance rate $( \pm \mathrm{SE})$ of mussels exposed to seston treatments for $4 \mathrm{~h}$. Significant ( $p<$ 0.05 . Tukey's multiple range analysis) differences are denoted by different letters above bars

quality (SQ ca 70\%) seston respectively, to a maximum of $87 \%$, when exposed to medium quality seston ( $\mathrm{SQ}=$ 25 to $60 \%$ ). The observed relationship (Fig. 5) suggests that a SEF 'optimum' exists that is dependent on the quality of the seston to which the mussel is exposed, with a predicted maximum SEF occurring at a SQ of $40 \%$. For comparative purposes, data of Bayne et al. (1993) (as open circles) have been included on Fig. 5

\section{Effect of seston matrices on pseudofaeces production}

Mussels always produced pseudofaeces when exposed to seston treatments, with the exception of one seston matrix (1.4 $\mathrm{mg}$ algae $\left.\mathrm{l}^{-1}\right)$ that was below the threshold for pseudofaeces production (Table 4). Pseu-

Table 4. Results of behavioural and physiological data on mussels. $C R=$ clearance rate, $P F_{c}=$ pseudofaeces production, $I R_{c}=$ ingestion rate, app and true $\mathrm{C}-\mathrm{AE} \%=$ apparent and true assimilation efficiency of carbon. Values are means $\pm \mathrm{SE}$; na $=$ not available, diet concentrations were below critical value for producing pseudofaeces

\begin{tabular}{|c|c|c|c|c|c|c|c|c|}
\hline \multicolumn{2}{|c|}{ Seston } & $\begin{array}{c}\text { CR } \\
\left(1 \mathrm{~h}^{-1} \mathrm{gdw} w^{-1}\right)\end{array}$ & $\begin{array}{c}P F_{c} \\
\left(m g h^{-1} g d w^{-1}\right)\end{array}$ & $\begin{array}{c}\mathrm{IR}_{c} \\
\left(\mathrm{mg} \mathrm{h}^{-1} \mathrm{gdw^{-1 }}\right)\end{array}$ & $\begin{array}{l}I_{\text {POM }} \\
\left(\mathrm{mg} \mathrm{h}^{-1} \mathrm{gdw} \mathrm{w}^{-1}\right)\end{array}$ & $\begin{array}{c}I R_{\mathrm{P} M} \mathrm{M}_{\mathrm{c}} \\
\left(\mathrm{mg} \mathrm{h} \mathrm{h}^{-1} \mathrm{gdw}^{-1}\right)\end{array}$ & App C-AE\% & True C-AE\% \\
\hline 5 & 0 & $14.4 \pm 0.81$ & na & $20.1 \pm 1.13$ & $20.1 \pm 1.13$ & - & 95 & 100 \\
\hline 20 & & $8.3 \pm 0.92$ & $7.4 \pm 0.27$ & $15.9 \pm 2.33$ & $15.9 \pm 2.33$ & - & $54.2 \pm 0.31$ & $87.8 \pm 2.90$ \\
\hline 150 & & $4.9 \pm 0.34$ & $29.6 \pm 3.60$ & $48.0 \pm 5.41$ & $48.0 \pm 5.41$ & - & $89.7 \pm 0.67$ & $63.1 \pm 2.89$ \\
\hline 5 & 5 & $18.0 \pm 2.09$ & $8.0 \pm 1.89$ & $89.6 \pm 11.35$ & $36.8 \pm 4.31$ & $52.9 \pm 7.04$ & $34.2 \pm 0.95$ & $70.2 \pm 7.95$ \\
\hline 20 & & $13.5 \pm 1.25$ & $29.2 \pm 10.80$ & $108.1 \pm 12.74$ & $28.9 \pm 2.77$ & $79.1 \pm 8.30$ & $7.4 \pm 4.43$ & $79.8 \pm 4.89$ \\
\hline 150 & & $3.3 \pm 0.36$ & $58.3 \pm 12.85$ & $21.0 \pm 3.09$ & $21.0 \pm 3.09$ & - & $23.4 \pm 0.10$ & $48.0 \pm 6.97$ \\
\hline 5 & 20 & $5.9 \pm 0.33$ & $13.6 \pm 0.53$ & $124.1 \pm 8.22$ & $21.2 \pm 1.32$ & $101.5 \pm 6.91$ & $2.4 \pm 0.98$ & $93.6 \pm 0.71$ \\
\hline 20 & & $21.8 \pm 2.12$ & $188.2 \pm 65.24$ & $411.1 \pm 55.30$ & $135.3 \pm 15.14$ & $275.8 \pm 34.32$ & $8.0 \pm 2.62$ & $95.2 \pm 1.82$ \\
\hline 150 & & $3.7 \pm 0.26$ & $122.2 \pm 24.38$ & $38.1 \pm 4.18$ & $38.1 \pm 4.18$ & - & $5.2 \pm 0.25$ & $23.5 \pm 2.61$ \\
\hline 5 & 50 & $5.6 \pm 0.44$ & $39.7 \pm 10.36$ & $130.1 \pm 13.35$ & $28.5 \pm 2.54$ & $101.6 \pm 10.81$ & $20.7 \pm 0.46$ & $93.7 \pm 0.5$ \\
\hline 20 & & $10.4 \pm 0.56$ & $104.3 \pm 27.33$ & $345.8 \pm 24.40$ & $55.3 \pm 3.42$ & $290.4 \pm 20.98$ & $80.6 \pm 0.41$ & $98.9 \pm 0.4$ \\
\hline 150 & & $5.2 \pm 0.49$ & $339.8 \pm 17.68$ & $91.3 \pm 9.87$ & $91.3 \neq 9.87$ & - & $30.5 \pm 0.10$ & $93.2 \pm 1.0$ \\
\hline
\end{tabular}



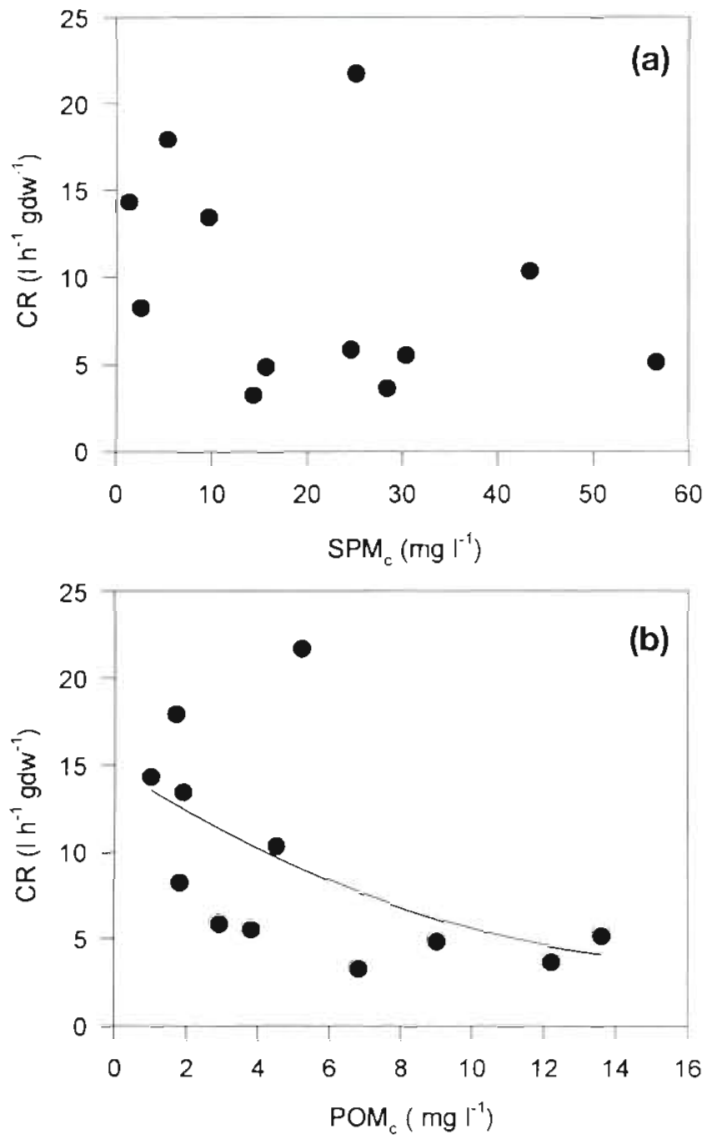

Fig. 4. Mytilus trossulus. Relationship between (a) seston quantity and clearance rate, and (b) seston organic content and clearance rate

dofaeces production was independent of seston quality (Fig. 6a), but increased as seston quantity increased $\left[P F_{C}=4.47\left(S_{C M}\right)-15.77 ; r^{2}=0.63, p<0.05\right]$ (Fig. 6b)

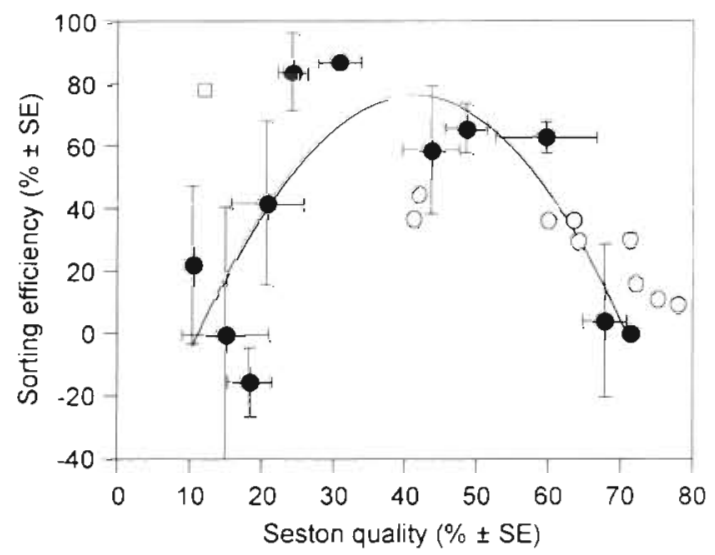

Fig. 5. Mytilus trossulus. Relationship between seston quality $(\mathrm{SQ} \pm \mathrm{SE})$ and sorting process $(\mathrm{SEF} \pm \mathrm{SE}) . \mathrm{SEF}=-0.086(\mathrm{SQ})^{2}+$ $7.019(\mathrm{SQ})-67.648, \mathrm{r}^{2}=0.60, \mathrm{n}=11 ;$ (0) SEF data from Bayne et al. (1993); (ㅁ) outlier
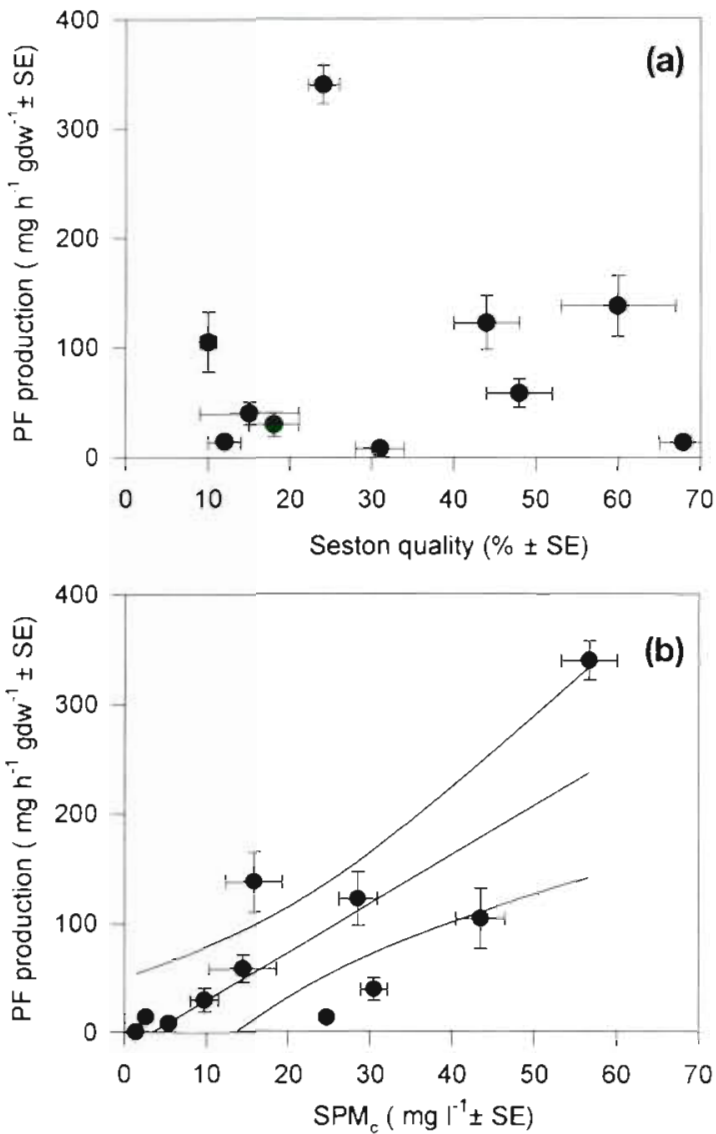

Fig. 6. Mytilus trossulus. Relationship between (a) seston quality and pseudofaeces production, (b) seston quantity and pseudofaeces production. $\mathrm{PF}_{\mathrm{c}}=4.47\left(\mathrm{SPM}_{\mathrm{c}}\right)-15.77$; values shown are $\pm 95 \%$ confidence intervals, $r^{2}=0.63, n=11$

The highest rate of pseudofaeces production was $339.8 \mathrm{mg} \mathrm{h}^{-1} \mathrm{gdw}^{-1}$ which was associated with highest seston quantity exposure (56.6 $\mathrm{mg} \mathrm{l}^{-1}$ ).

\section{Effect of seston matrices on $\mathrm{POM}_{\mathrm{c}}$ and PIM ingestion rates}

IRs are the product of CRs and $\mathrm{SPM}_{\mathrm{c}}$ corrected for PF production and are a true measure of the actual 'diet' to which the mussel is exposed. IRs were calculated for both organic $\left(\mathrm{POM}_{c}\right)$ and inorganic $\left(\mathrm{PIM}_{c}\right)$ seston components. Total IR $\left(\mathrm{POM}_{\mathrm{C}}+\mathrm{PIM}_{\mathrm{C}}\right)$ as well as POM and $\mathrm{PIM}_{c}$ IRs are presented in Fig 7 . There was a general increase in total IRs with increasing seston quantity, with maximum rates occurring at mid-algae $\left(20 \times 10^{6}\right.$ cells $\left.1^{-1}\right)$ and high silt loads (20 and $50 \mathrm{mg} \mathrm{l}^{-1}$ silt). At these maxima, both $\mathrm{PIM}_{c}$ and $\mathrm{POM}_{c}$ seston components were being selected by the mussel for ingestion. Of most importance was the observation that at the highest silt and algae exposures, mussels were capable of selecting only the organic component of 


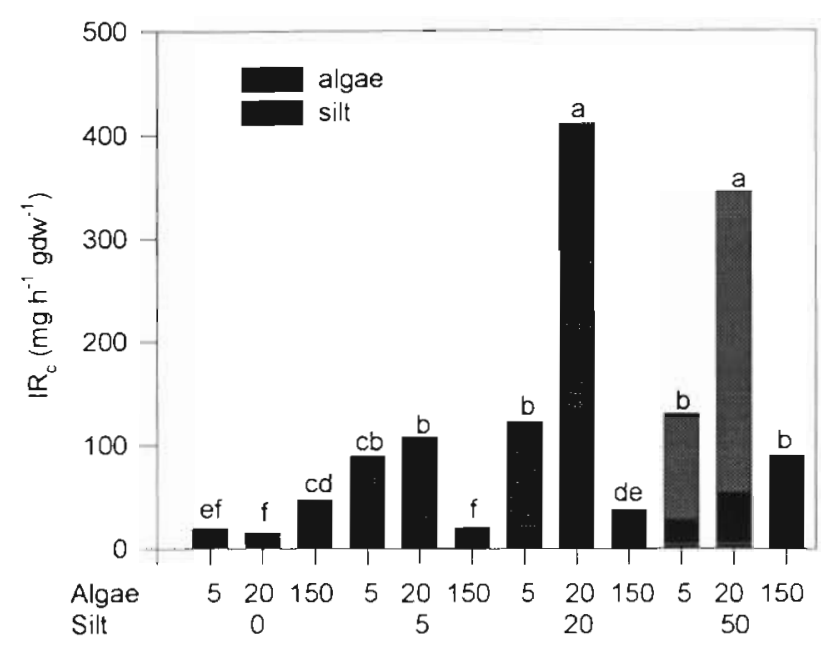

Fig. 7. Mytilus trossulus. Ingestion rate of mussels under different seston matrices. Significant ( $p<0.05$. Tukey's multiple range analysis) differences are denote as different letters

the seston, i.e. the 'diet' of the mussel comprised only $\mathrm{POM}_{c}$ rather than $\mathrm{POM}_{c}+\mathrm{PIM}_{c}$ as was noted for the lower quality and quantity seston, exposures. Hence, mussels showed a highly selective feeding behaviour by ingesting only the organic component of seston and excluding almost all inorganic particles (silt) when exposed to a high quantity of seston, regardless of their

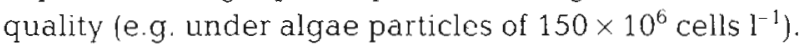
However, under low $\left(5 \times 10^{6}\right.$ cells $\left.\mathrm{l}^{-1}\right)$ and medium $\left(20 \times 10^{6}\right.$ cells $\left.1^{-1}\right)$ organic exposures, increasing silt loads resulted in the ingestion of both $\mathrm{POM}_{c}$ and $\mathrm{PIM}_{C}$ by the mussel. There was a weak relationship between $I_{P O M} c$ and the organic content of the seston $\left(\mathrm{POM}_{\mathrm{C}}\right.$ $\left.\mathrm{mg}^{-1}\right)\left(\mathrm{r}^{2}=0.50, \mathrm{p}=0.05 ; \mathrm{Fig} .8\right)$. However, this rela-

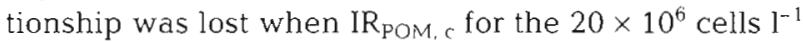
and $20 \mathrm{mg} \mathrm{l}^{-1}$ silt treatments was included within the

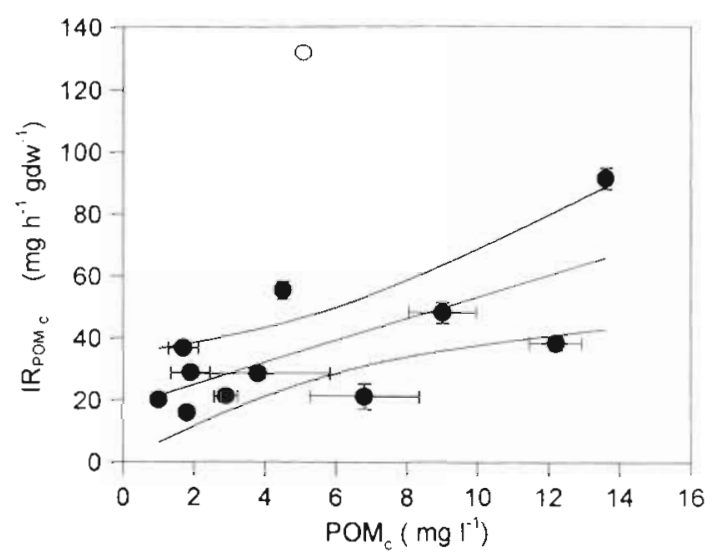

Fig. 8. Mytilus trossulus. Relationship between particulate organic matter $\left(\mathrm{POM}_{c}\right)$ and ingestion rates of organic matter $I R_{\mathrm{POM}, \mathrm{C}} \cdot \mathrm{IR}_{\mathrm{POM}, \mathrm{C}}=3.495\left(\mathrm{POM}_{\mathrm{c}}\right)+18.019 ; 95 \%$ confidence interval, $\mathrm{r}^{2}=0.50, \mathrm{n}=11,(0)$ maximum CR (algae $:$ silt $=20: 20$ ) regression, i.e the maximum clearance rates observed under this exposure regime resulted in the greatest rates of organic matter ingestion, even though the seston was of low quality.

\section{Effect of seston matrices on carbon assimilation efficiency}

App C-AE\% was dependent on seston quality (as compared to 'diet') (Fig. $9 a, r^{2}=0.64$ ). However, when the true $\mathrm{C}-\mathrm{AE} \%$ was regressed against seston quality, which accounts for the selective sorting process that occurred under the various exposure regimes (Fig. 9b), this relationship was lost. Seston matrices with the highest algae concentrations (denoted as open squares) generally displayed the lowest true C-AE\% and, when viewed independently from all other data, C-AE\% for these matrices
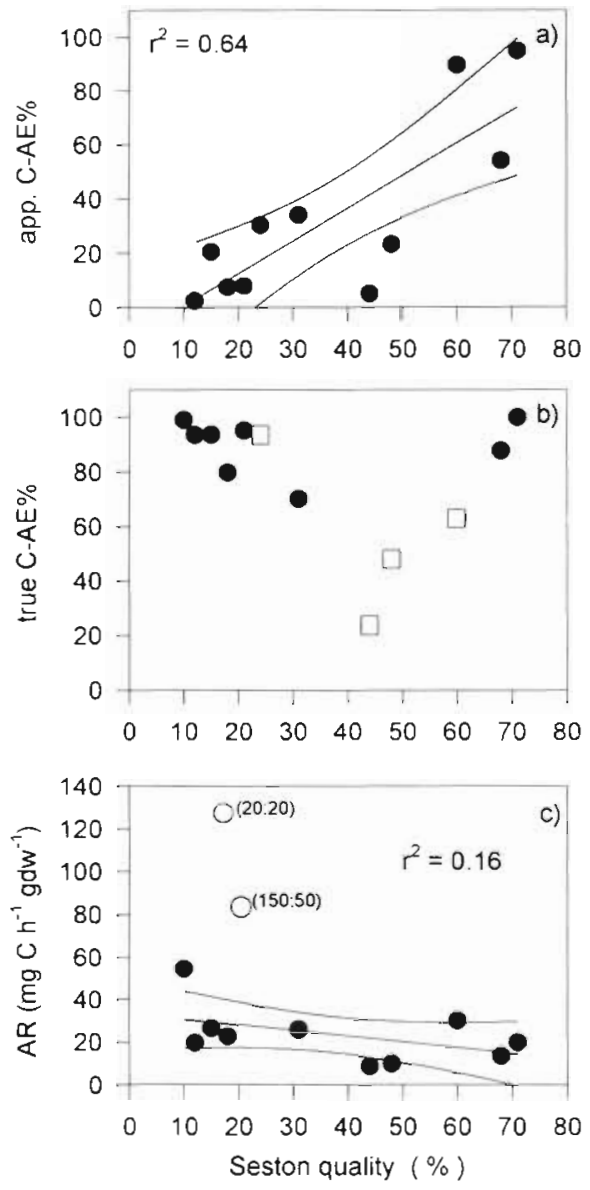

Fig. 9. Mytilus trossulus. Relationship between: (a) seston quality and apparent carbon assimilation, app $\mathrm{C}-\mathrm{AE} \%=$ $1.204(\mathrm{SQ})-11.397, \mathrm{r}^{2}=0.64, \mathrm{n}=11$; (b) seston quality and true assimilation efficiency; ( $\square$ ) data with high algae concentration, i.e. $150 \times 10^{6}$ cells $1^{-1}$; (c) seston quality and carbon assimilation rate 
was positively correlated to seston quality. When expressed as a carbon assimilation rate (Fig. 9c) (a measure of the amount of carbon absorbed from the diet by the mussels, given the amount of organic matter ingested over the 4 h exposure period), these values were no longer distinct. Rather, the rate at which carbon was assimilated by the mussel was independent of seston quality. Greatest rates of carbon assimilation corresponded to treatments in which maximum clearance rates were observed and in which seston matrices were comprised of the highest algae and silt loads

\section{DISCUSSION}

Numerous studies have addressed the feeding behaviour of the mussel under changing seston conditions (e.g. Winter 1973, Bayne et al. 1989, Bayne et al 1993, Clausen \& Riisgård 1996, Navarro et al. 1996) From our perspective, however, we were attempting to elucidate the possible role a selective feeding strategy may have in determining what part of the total seston the mussel is ingesting and the corresponding carbon assimilation efficiency from the 'diet' as selected for by the mussel. Assuming that for some metals (e.g. cadmium; Wang \& Fisher 1996) assimilation follows a diet/energy pathway, ultimately this information can be used to improve existing models which predict uptake and accumulation of metals by filter-feeding organisms.

\section{Behavioural response to a changing food environment}

Two paradigms with respect to the feeding behaviour of the mussel currently exist within the literature: (1) that they have the ability to respond to changes in their food environment and (2) mussels are mere physiological slaves to their environment. If the former applies, then it is feasible that, as shown by Bayne et al. (1993), the composition of seston in the environment and what the mussel is actually ingesting (i.e. the diet) are not the same. If, however, the latter paradigm is true, as suggested by Jørgensen (1990) and Clausen \& Riisgård (1996), then the mussel is not selective and has evolved to filter at an optimal rate, regardless of changing environmental conditions.

An important aspect of our study was that we exposed mussels to a wide range of seston conditions that have been measured within the natural environment. Our experimental 'envelope' included conditions representative of the area from which the mussels were sampled, as well as extremes that have been noted within other systems (Table 1 ). This range allows our data to be compared to previous studies on the behavioural response of the blue mussel to a changing food environment (e.g Bayne et al. 1989, 1993, Clausen \& Riisgård 1996). Our findings suggest that both paradigms in regards to the feeding behaviour of the mussel are true

As in other studies (e.g. Winter 1973, Bayne et al. 1989, Clausen \& Riisgård 1996), we found that, under low silt regimes ( 0 and $5 \mathrm{mg} \mathrm{l}^{-1}$ ), CRs decreased as algae concentrations increased. Clausen \& Riisgård (1996) interpreted this result as being a consequence of the mussel simply closing its inhalant siphon to avoid smothering under less than optimal conditions. In contrast, Bayne et al. (1989) suggested that a reduced clearance rate is a selective response of the mussel to conditions of higher food quality. Importantly, in our study, if mussels were simply closing down in response to less than optimal conditions as suggested by Clausen \& Risgård (1996), the maximum clearance rates at the higher silt and algae loads would not have been observed. This observation, plus the response of the mussel to increasing algae concentrations, supports the findings of Bayne et al. (1993), in that mussels are capable of a compensatory feeding behaviour which allows full exploitation of its food environment.

However, Riisgård \& Larsen (1995) recently reviewed the literature on the filter-feeding characteristics of marine invertebrates and concluded that filterfeeders are phylogenetically adapted to pump water continuously at rates characteristics of the species, i.e. in filter-feeding bivalves, the bivalve pump is the evolutionary result of the interaction between the organism and its biotope. Our results support this conclusion, as well as that of Bayne et al. (1989), in that maximum ingestion rates for mussels used in the study were observed under seston exposure regimes that would be considered less than optimal for the mussel. This maximum (at mid-algae and mid-silt-load seston exposures) most likely corresponds to the predetermined filter-feeding rate characteristic of this species for this particular estuary. However, under increasing algal concentrations, and under extremely high silt loads, mussels were also able to move from this filtering 'optimum' and adapt their feeding strategy to maximize organic matter ingestion by selecting only organicrich particles and rejecting inorganic particles. Such an adaptive ability, either through altering clearance rates and/or increasing SEFs, on the part of Mytilus trossulus would indeed be advantageous under rapid and continuous changing quality and quantity of seston, such as that noted by Stecko (1997) for the coastal area from which the experimental mussels were sampled

In their studies on the feeding response of the blue mussel challenged with diet matrices of differing quality and quantity, Bayne et al. (1993) noted that as 
the organic content of the diet increased ( 43 to $81 \%$ ), SEFs decreased. Similarly, we found that in our higher quality seston matrices, SEF declined as quality increased, with our data comparing well with the data of Bayne et al. (1993). However SEFs also declined under poor quality seston exposures. Under conditions of a poor quality diet, the selection of organic versus inorganic particles is negligible as the mussel attempts to meet its energy requirement by incorporating all seston components. Similarly, in high quality seston matrices (i.e. just algae alone), and as noted by Bayne et al. (1993), no sorting is required, i.e. there is no inorganic material to reject; hence again SEFs are low. Maximum SEFs (a SEF optimum) were observed when seston quality was approximately $40 \%$, i.e. under conditions where the algal concentrations were high enough that, despite an increasing silt load, the mussel could effectively improve diet quality by selecting only' the algae component of the seston.

\section{Assimilation of carbon in varying seston matrices}

The rate of absorption of carbon by the blue mussel has previously been shown to be dependent on seston quality (Bayne et al. 1987). Iglesias et al. (1996) have also noted that the absorption efficiency of carbon by the cockle Cerastoderma edule (L.) was dependent on the organic content of ingested matter according to an exponential saturating function, i.e. carbon absorption positively increased to an organic matter content of ingested matter of approximately $45 \%$, at which point carbon absorption became independent of organic content.

When expressed as an app C-AE\% versus seston quality, we also noted a positive relationship, i.e. carbon assimilation by the mussel was positively correlated with increasing seston organic content. When expressed as a true C-AE\%, however, carbon assimilation was independent of seston quality. True $\mathrm{C}$ $A E \%$ for the exposure regimes which contained the largest amount of algae, when viewed independently from the remaining data, appeared to be dependent on increasing seston quality. When expressed as a carbon assimilation rate (i.e. a measure of the actual amount of carbon assimilated by the mussel given the amount of $\mathrm{POM}_{\mathrm{c}}$ the mussel has ingested over the $4 \mathrm{~h}$ feeding period), the rate of carbon assimilation by the musssel was independent of seston quality. In other words, through a dynamic interplay of carbon assimilation (which is in turn dependent on gut resident time and digestive processes) and clearance rates, the blue mussel is able to maintain a constant rate of carbon assimilation-on average $29.3 \pm$ 6.9 (SE) $\mathrm{mg} \mathrm{C} \mathrm{h}^{-1} \mathrm{gdw}^{-1}$, with the maximum carbon assimilation rate where clearance rates were optimized being omitted from the overall averageregardless of the seston matrix to which it has been exposed.

Our findings differ from those of Bayne et al. (1993) who noted that the rate of carbon absorption by the blue mussel was dependent on POM (mg l-1). In the studies of Bayne et al. (1993) POM concentrations and seston quality ranged only from 0.63 to $5.85 \mathrm{mg} \mathrm{l}^{-1}$ and 53 to $97 \%$ respectively. In contrast, $\mathrm{POM}_{\mathrm{C}}$ concentrations and seston quality for our experiments ranged from 1.0 to $13.6 \mathrm{mg}^{-1}$ and 10 to $71 \%$ respectively. Hence, the greater scope of the diet exposure regime may have resulted in different relationships being observed. It is also possible that the relationship noted by Bayne et al. (1993) was a consequence of the strong relationship between mussel filtration rate and total particulate matter (mg $\mathrm{1}^{-1}$ ) that occurred in their studies. As found in our study and that of Bayne et al. (1993), carbon assimilation rates are a product of ingestion rates and carbon absorption efficiency. Ingestion rates are, in turn, dependent on filtration rates. Bayne et al. (1993) noted no consistent differences in absorption efficiencies for their various $2 \mathrm{~d}$ diet exposure regimes, i.e. carbon absorption was constant over the various exposure regimes. It is possible that their observed relationship between carbon assimilation rate and $\mathrm{POM}_{\mathrm{c}}$ was driven mostly by differences in mussel filtration rates among the various diet regimes as opposed to reflecting the interplay between carbon assimilation efficiences and mussel filtration rates.

In summary, our findings suggest that the mussel is capable of 2 feeding strategies which are not mutually exclusive. As concluded by Riisgård \& Larsen (1995) and Clausen \& Riisgård (1996), mussels have a filtering 'optimum' that is predetermined by the phylogeny of the species. In our study, this filtering optimum by the blue mussel was obtained at an algae and silt concentration of $20 \times 10^{6}$ cells $^{-1}$ and $20 \mathrm{mg}$ $l^{-1}$ respectively, concentrations which would have been considered less than 'optimum' by the studies of Clausen \& Riisgård (1996). Further, at this filtering 'optimum', maximum carbon assimilation rates were observed. In addition, as proposed by Bayne et al. (1993), mussels have the ability to physiologically respond to a changing food environment. We found that at the highest silt and algae seston exposures, mussels were capable of selecting only the organic components of seston (i.e. high SEF) and rejecting the inorganic components of seston (through PF production). In the absence of silts, mussels decreased CRs with increasing algae concentrations, while maintaining $\mathrm{POM}_{c}$ ingesting rates. Hence, Mytilus trossulus was generally able to optimize diet quality and car- 
bon assimilation rates, with the maximum carbon assimilation rate occurring at what could be a phylogenetically determined filtering optimum for the mussels used for these studies.

\section{Ecological implications for contaminant exposure via food sources}

Our findings indicate that seston as measured in the environment is not what the mussel is actually consuming, and depending on the quality and quantity of the seston, the mussel has the ability to select either organic particles or both inorganic and organic particles for ingestion. For example, under conditions of high silt and high algae (e.g. during a seasonal algae bloom), the blue mussel will effectively exclude inorganic particles from its diet, creating a diet that is $100 \%$ organic matter. If this sorting process has not been considered, predicted metal assimilation will be underestimated, as carbon assimilation rates based on the organic content of the seston uncorrected for a compensatory feeding strategy would also be underestimated. Further, and of relevance for trace metals that can be associated with the inorganic portion of seston, a sorting process which virtually excludes the inorganic seston component implies that any contaminants associated with this fraction of seston would not be ingested and hence not available to the mussel for uptake. In contrast, when environmental concentrations and quality of seston are low (e.g. during periods of low flow within an estuarine environment), the mussel will respond to the number of particles in the water column, independently of seston composition, and ingest both inorganic and organic particles regardless of the nutritional quality of the seston matrix. In this situation, contaminants associated with both components of the seston will be ingested by the mussel. It is likely that it is under these types of conditions (i.e. when the organic content of the seston is low, with mussels ingesting both inorganic and organic particles) that the mussel filters at its phylogenetically determined 'optimum', as proposed by Clausen \& Riisgård (1996). If indeed this does occur, then it would be necessary to determine this filtering optimum for mussels used in any type of pollution monitoring program, for it would be at this optimum that carbon assimilation rate and hence contaminant uptake would be maximized

Our further studies are directed at determining the influence of seston quality and quantity on the assimilation rate of trace metals. Ultimately, this information will be used to build better predictive models for determining factors which determine trace metal burdens of filter-feeding organisms
Acknowledgements. This research was supported in part by a CIDA graduate-fellowship to Z.A. through the ASEANCanada Marine Science Project, as well as an NSERCoperating grant to L.B.Y. The field assistance of Kirsty Bennett and Tei Kyung is gratefully acknowledged. The thoughtful advice of Dr L. Dill is also gratefully acknowledged.

\section{LITERATURE CITED}

Bayne BL, Hawkıns AJS, Navarro E (1987) Feeding and digestion by the mussel Mytilus edulis L. (Bivalvia: Molusca) in mixtures of sllt and algal cells at low concentrations. J Exp Mar Biol Ecol 111:1-22

Bayne BL, Hawkins AJS, Navarro E, Iglesias JIP (1989) Effects of seston concentration on feeding, digestion and growth in the mussel Mytilus edulis. Mar Ecol Prog Ser $55: 47-54$

Bayne BL, Iglesias JIP, Hawkins AJS, Navarro E, Heral M, Deslous-Paoli JM (1993) Feeding behaviour of the mussel Mytilus edulis: responses to variations in quantity and organic content of the seston. J Mar Biol Assoc UK 73: $813-829$

Berg JA, Newell RIE (1986) Temporal and spatial variations in the composition of seston avatlable to the suspension feeder Crassostrea virginica. Estuar Coast Shelf Sci 23: $375-386$

Clausen I, Riisgård HU (1996) Growth, filtration and respiration in the mussel Mytilus edulis: no evidence for physiological regulation of the filter-pump to meet nutritional needs. Mar Ecol Prog Ser 141:37-45

Cossa D, Bourget E, Piuze J (1979) Sexual maturation as a source of variation in the relationship between cadmium and body weight of Mytilus edulis. Mar Pollut Bull 10: $174-176$

Decho AW, Luoma S (1996) Flexible digestion strategies and trace metal assimilation in marine bivalves. Limnol Oceanogr 41:568-572

Fegley SR, McDonalds BA, Jacobsen TR (1992) Short-term variation in the quantity and quality of seston available to benthic suspension feeders. Estuar Coast Shelf Sc1 34: $393-412$

Galois R, Richard P, Fricourt B (1996) Seasonal variation in suspended particulate matter in the Merennes-Oleron Bay, France, using lipids as biomarkers. Estuar Coast Shelf Sci 43:335-357

Griffiths RJ (1980) Natural food availability and assimilation in the bivalve Choromytilus meridionalis. Mar Ecol Prog Ser 3:151-156

Harrison PJ, Waters RE, Taylor FJR (1980) A broad spectrum artificial seawater medium for coastal and open ocean phytoplankton. J Phycol 16:28-35

Iglesias JIP, Urrutia MB, Navarro E, Alvarez-Jorna P, Larretxea X, Bougner S, Heral M (1996) Variability of feeding processes in the cockle Cerastoderma edule $(\mathrm{L})$ in response to changes in seston concentration and composition. J Exp Mar Biol Ecol 197:121-143

Jørgensen CB (1990) Bivalve filter feeding: hydrodynamics, bioenergetics, physiology and ecology. Olsen and Olsen. Fredenborg

Lobel PB, Bajdik CD, Belkhonde SP, Jakson SE, Longerich HP (1991) Improved protocol for collecting mussel watch specimens taking into account sex, size, condition index, shell shape and chronological age. Arch Environ Contam Toxicol 102:513-518

MacDonald BA. Ward JE (1994) Variation in food quality and particle selectivity in the sea scallop Placopecten magel- 
lanicus (Mollusca: Bivalvia). Mar Ecol Prog Ser 108: $251-264$

Navarro JM. Clasing E, Urrutia G, Asenicio G, Stead R, Herrera $C$ (1993) Biochemical composition and nutritive value of suspended particulate matter over a tidal flat of southern Chile. Estuar Coast Shelf Sci 37:59-73

Navarro JM, Iglesias JIP, Camacho AP, Labarta U (1996) The effect of diets of phytoplankton and suspended bottom material on feeding and absorption of raft mussels (Mytilus galloprovincialis Lmk). J Exp Mar Biol Ecol 198: $175-189$

Navarro JM, Thompson RJ (1995) Seasonal fluctuation in the size spectra, biochemical composition and nutritive value of the seston available to a suspension-feeding bivalve in a subartic environment. Mar Ecol Prog Ser 125:95-106

Poulsen E, Riisgård HU, Mohlenberg F (1982) Accumulation of cadmium and bioenergetics in the mussel Mytilus edulis. Mar Biol 68:25-29

Riisgărd HU, Larsen PS (1995) Filter-feeding in marine macro-invertebrates: pump characteristics, modelling and energy cost. Biol Rev 70:67-106

Schubel JR (1971) Tidal variation of the size distribution of suspended sediment at a station in the Chesapeake Bdy turbidity maximum. Neth J Sea Res 2:252-266

Smaal AC, Verhagen JHG, Coosen J, Hass HA (1986) Interaction between seston quantity and quality and benthic

Editorial responsibility: Otto Kinne (Editor),

Oldendorl/Luhe, Germany suspension feeders in the Oosterschelde. The Netherlands. Ophelia 26:385-399

Stecko JRP (1997) Contrasting the geochemistry of suspended particulate matter and deposited sediments of the Fraser River estuary: implications for metal exposure and uptake in estuarine deposit and filter feeders. MSc thesis, Dept of Brological Sciences, Simon Fraser University, Burnaby

Vahl O (1972) Efficiency of particle retention in Mytilus eduls L. Ophelia 10:17-25

Vahl O (1973) Pumping and oxygen consumption rates of Mytilus edulis L. of different sizes. Ophelı 12:45-52

Vah! O (1980) Seasonal variation in seston and in the growth rate of the Iceland scallop, Chlamys islandica (O.F. Muller) from Balsfjord $70^{\circ} \mathrm{N}$.J Exp Mar Biol Ecol 48:195-204

Wang WX, Fisher NS (1996) Assimilation of trace elements and carbon by the mussel Mytilus edulis: effects of food composition. Limnol Oceanogr 41:197-207

Wang WX, Fisher NS, Luoma S (1995) Assimilation of trace elements ingested by the mussel Mytilus edulis: effects of algal food abundance. Mar Ecol Prog Ser 129:165-176

Widdows J, Fieth P, Worrall CM (1979) Relationships between seston, available food and feeding activity in the common mussel (Mytilus edulis). Mar Biol 50:195-207

Winter JE (1973) The filtration rate of Mytilus edulis and its dependence on algal concentration, measured by a continuous automatic recording apparatus. Mar Biol 22:317-328

Submitted: June 23, 1997; Accepted: September 29, 1997 Proofs received from author(s): November 26, 1997 